急性感音難聴で発症した椎骨動脈瘤例

吉川 环磨 · 吉田 晋也

\title{
A Case of Vertebral Artery Aneurysm with Sensory Neural Hearing Loss
}

\author{
Takuma Yoshikawa and Shinya Yoshida \\ (Tachikawa Hospital, Kokka-koumuin Kyousaikumiai Rengoukai)
}

\begin{abstract}
Although vertebral artery aneurysm is uncommon, its rupture causes subarachnoid hemorrhage (SAH). It commenced with tinnitus, and hearing loss advanced during medical treatment as acute sensory neural healing loss. As ABR was revealed as only a wave I extension, MRI was performed. A well enhanced Cerebello pontain angle tumor was shown, and the aneurysm was found in the four vessel study.

The aneurysm was embolized using GDC coils and hearing loss advanced to deafness. It was thought that the unruptured aneurysm was enlarged and put pressure on the acoustic nerve.
\end{abstract}

Key words : vertebral artery aneurysm, sensory neural hearing loss, ABR, MRI

\section{はじめに}

椎骨動脈瘤は, 動脈溜全体のうち $1 \sim 2 \%$ の出現率と 報告されており ${ }^{122)}$, 後頭蓋窩の動脈溜のなかでも頻度の 高くない動脈瘤である. 巨大化したり血栓化して，圧迫 症状を呈して発症することもあるが，その多くは破裂に よるくも膜下出血で発見される. 今回, 耳鳴で受診し急 性感音難聴として加療中に難聴の進行をきたし, MRI に て小脳橋角部に腫瘤陰影を認め, 血管造影にて椎骨動脈 瘤と診断された 1 例を経験したので, 若干の文献的考察 を加えて報告する。

\section{症例}

症例 : 53 歳, 女性.

主訴：右耳鳴.

現病歴: 平成 11 年 11 月 1 日，右耳鳴を自覚し，耳閉 感, 難聴を伴い, 11 月 8 日当科を受診した.

既往歷，家族歴：特記すべきことなし.

初診時所見：めまい, 頭痛, 嘔気の訴えはなく, 両耳 鼓膜は正常であり, 眼振所見は認められなかった. 純音 聴力検査にて右低〜中音域の閾値上昇を認めた。
経過: 急性低音障害型感音難聴の診断にてビタミン剂, 循環改善剤などの投与と, 内耳への効果的な薬剤の浸透 を期待して L-V 療法を施行し, 聴力は $30 \mathrm{~dB}$ 以内に改善 した (図 1). 11 月 30 日に再度, $125 \sim 500 \mathrm{~Hz}$ の閾值上 昇を認めたため, 内リンパ水腫を疑い浸透圧利尿剂を追 加投与した. 2 週間内服するものの低音域の閾値上昇は 残存した.

経過観察中に耳鳴はほとんど気にならない程度にまで 改善したものの, 2 月 22 日に, さらに $1 \sim 2 \mathrm{kHz}$ の闇値 上昇を認めた（図 2)。聴神経腫場などを疑い, ABR を 施行したところ，右側は I 波潜時の延長および II 波以降 が消失していた（図 3)。また温度眼振検查では, 右半規 管高度麻痺であった。

聴神経腫瘍を疑い，MRIを施行したところ，右小脳橋 角部に T1 強調画像にて等〜高信号域, T2 強調画像にて 低信号域を認め, T1 ガドリニウム造影にて強くエンハン スされる腫瘤を認めた（図 4). 動脈瘤が疑われたため, 脳神経外科に依頼した。

平成 12 年 4 月 10 日, 脳神経外科にて血管造影を施行 し, 椎骨動脈に直径約 $20 \mathrm{~mm}$ の動脈瘤が確認された（図 


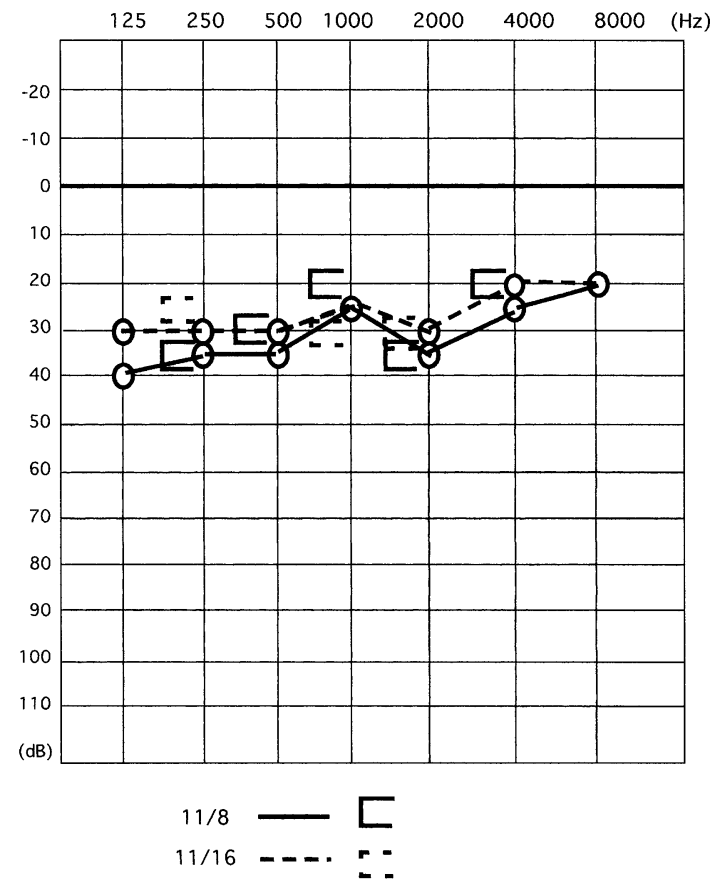

図 1 初診時および 1 週間後聴力検査

初診時右低〜中音域の感音難聴を認めた. 1 週間のビタミ ン剂, 循環改善剂などの投与と, L-V 療法にて聴力の改善 を認めた。

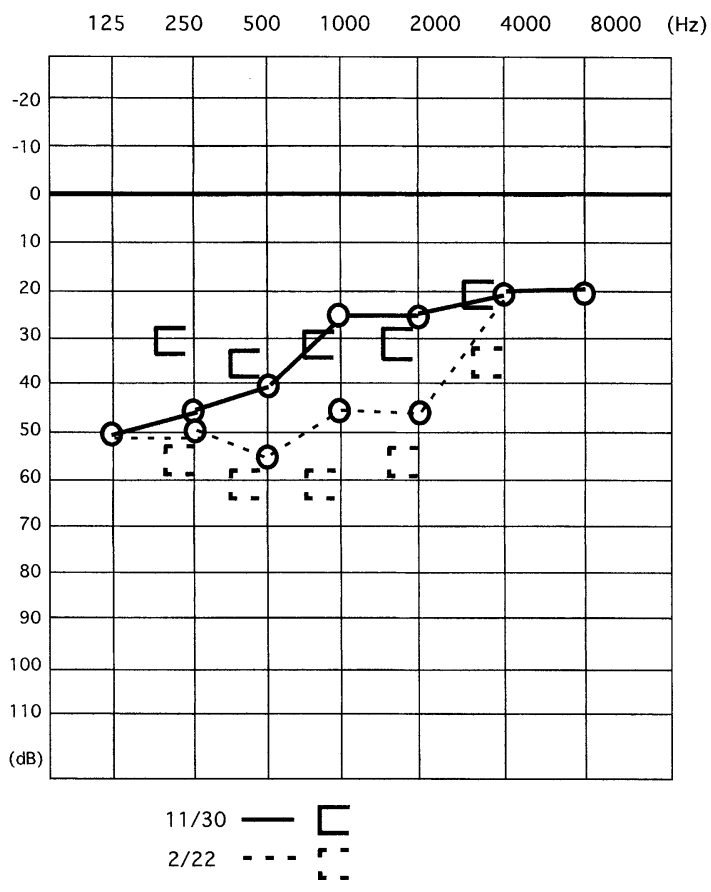

図 2 再度聴力低下時聴力検查

11月 30 日に再度, $125 \sim 500 \mathrm{~Hz}$ の閾値上昇を認めた. 浸 透圧利尿剤の追加投与にもかかわらず低音域の閾值上昇 は残存し, 2 月 22 日さらに $1 \sim 2 \mathrm{kHz}$ の閾值上昇を認めた.

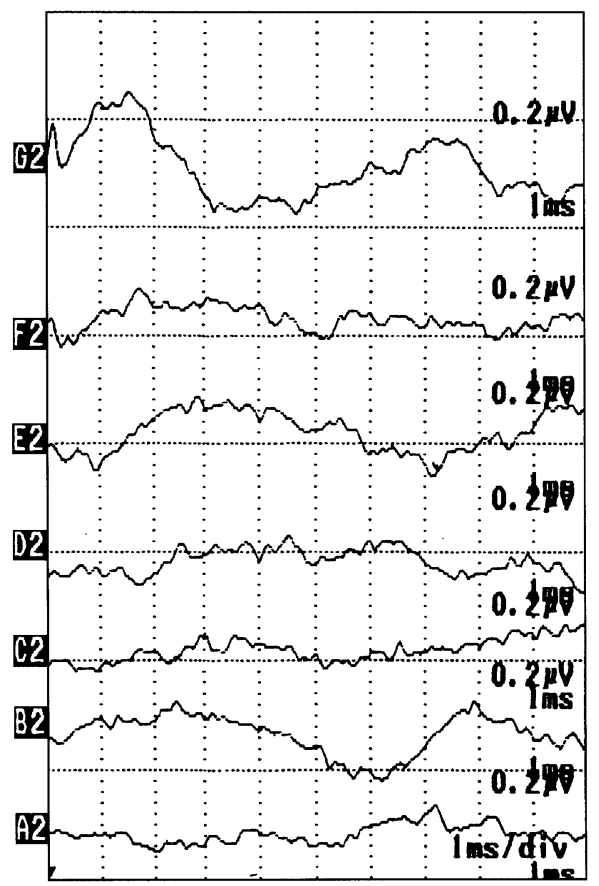

図 $3 A B R$ 所見

患側は $90 \mathrm{~dB}$ にて, I 波潜時の著明な延長および II 波以降が消失していた. 


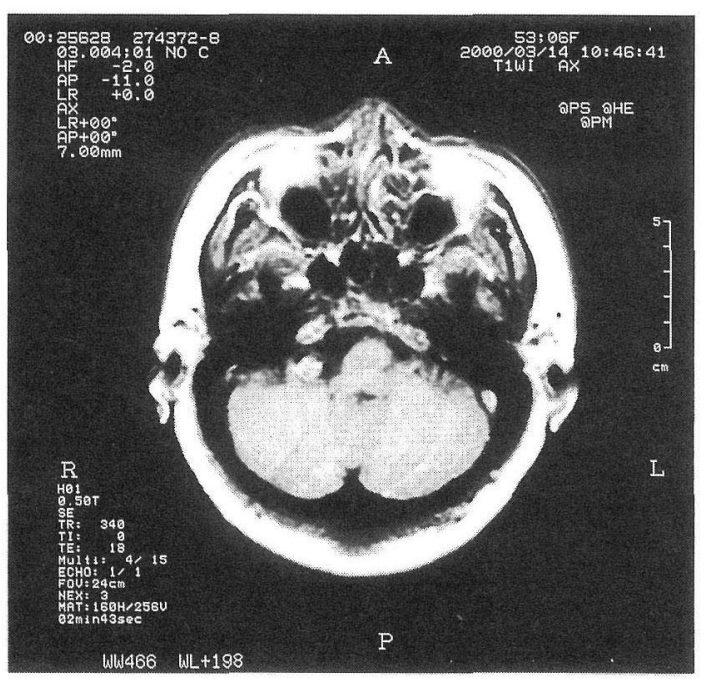

a

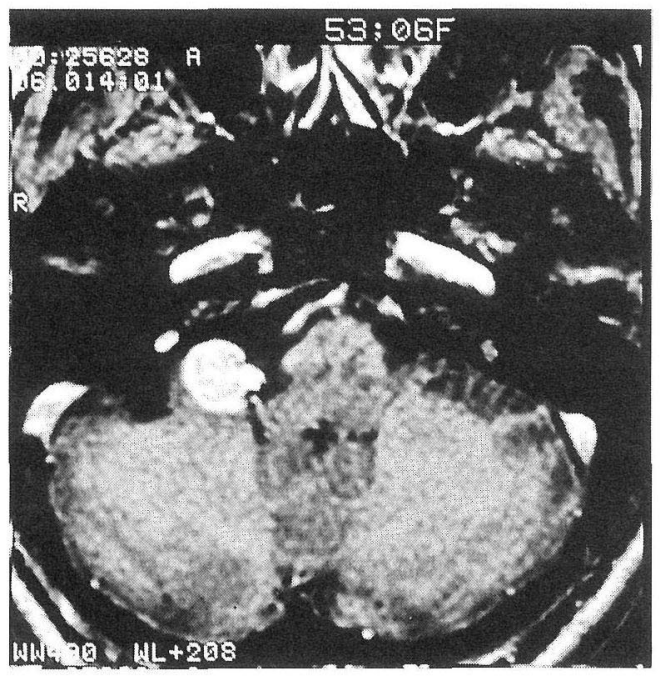

c

5)。5月 24 日 GDC コイルによる塞栓術を施行した。

塞栓術施行後の 6 月 9 日に当科再診したところ，耳鳴 は残存し，聴力の低下も認められ，純音聴力検查ではス ケールアウトであった。

\section{考察}

脳動脈瘤の発生頻度は内頸動脈系に $70 \sim 80 \%$, 中大 脳動脈系に $20 \%$ ，椎骨脳底動脈系に5\% と報告されてお り1)，椎骨脳底動脈系のらち $26 \%$ が椎骨動脈，68\%が後 下小脳動脈分岐部であり，椎骨動脈瘤は動脈瘤全体で 1 〜 $2 \%$ の出現率となる2). 大きさは 1 ～ $10 \mathrm{~mm}$ が多いが, 椎骨動脈瘤は比較的大きなものが認められる。破裂動脈

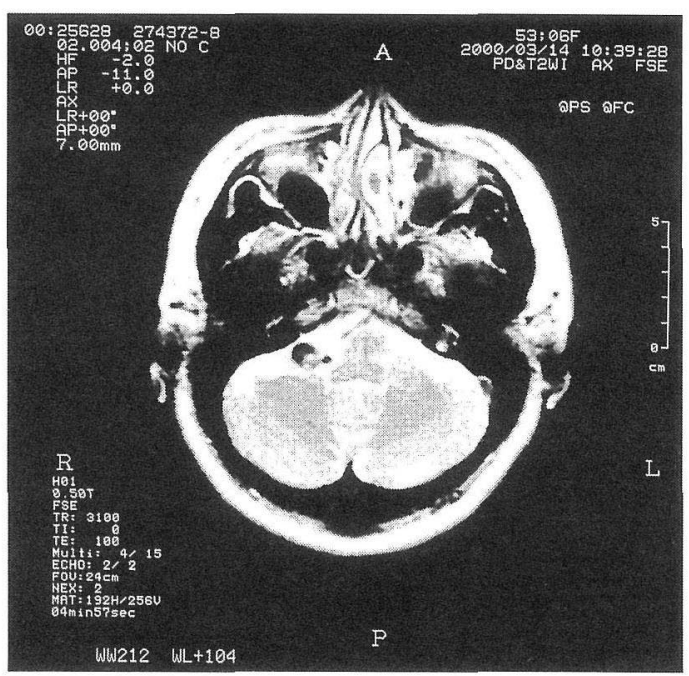

b

図 4 MRI 所見

$\mathrm{a}$ ：右小脳橋角部に T1 強調画像にて，等〜高信号域を認め た。

$\mathrm{b}$ ：右小脳橋角部に T2 強調画像にて, 低信号域を認めた.

$\mathrm{c}$ ：右小脳橋角部に $\mathrm{T} 1$ ガドリニウム造影にて強くエンハン スされる腫瘤を認めた。
瘤の出現頻度は，人口 10 万人めたり $11 \sim 29$ 人 $(0.01$ 〜 0.03\%）と報告されているが 1)3)，近年脳ドックなど で未破裂（無症候性）動脈瘤の発見が増えており，発生 頻度が 7\%との報告があり4)，また剖検例では $5 \%$ にみら れたとの報告もある1)。一度 SAH（くも膜下出血）を発 症した破裂動脈瘤のらち，多発動脈瘤の $1 / 2 \sim 1 / 3$ は破 裂すると報告されており5)，また動脈瘤患者の $20 \sim 30 \%$ が多発性動脈瘤とも報告されている6).

急性感音難聴の原因として，頭盖内病変に聴神経腫瘍 が挙げられ，全体の約 1\%を占めており7)，聴神経腫瘍 のらち急性感音難聴が初発症状のものは $3.2 \sim 26 \%$ と報 告されている8) 13). 画像診断の進歩により小腫瘍もみ 

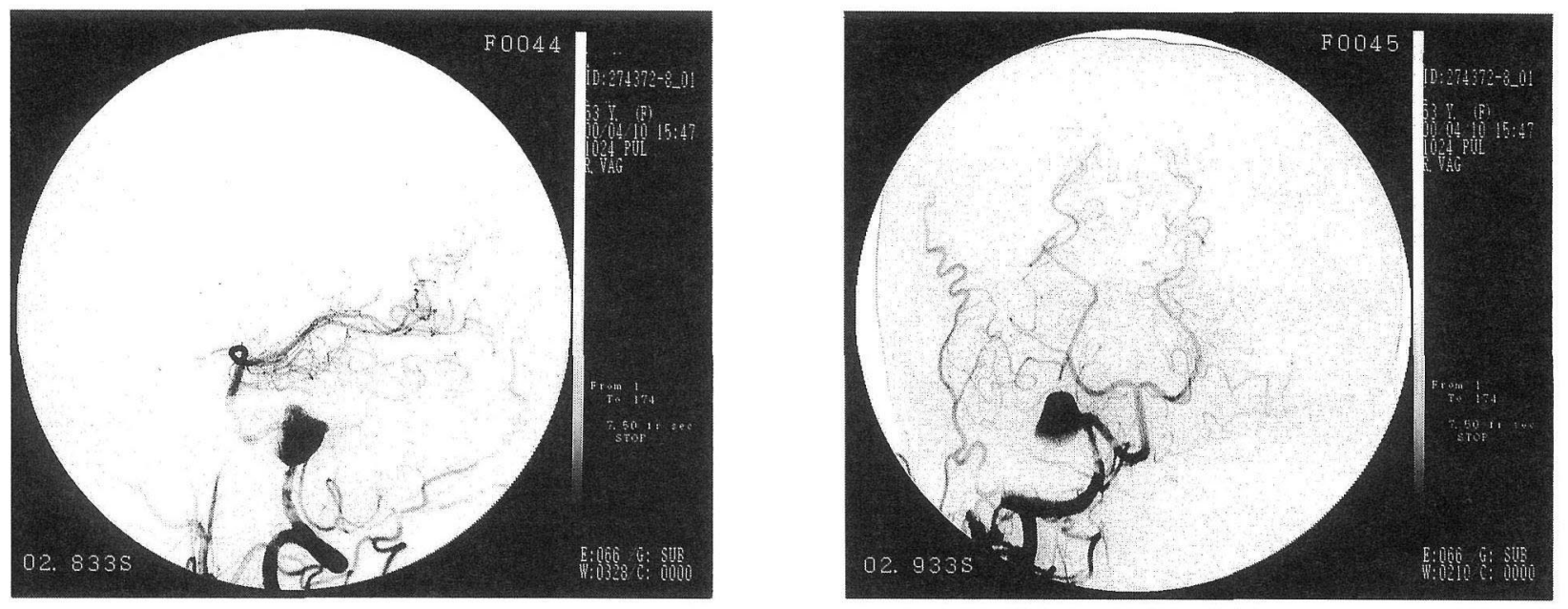

図 5 血管造影

椎骨動脈に直径約 $20 \mathrm{~mm}$ の動脈瘤を認めた.

つかるよらになり，頻度が高い報告がみられるように なってきた $\left.{ }^{11)} \sim 13\right)$ 。鑑別診断としての椎骨動脈瘤による 急性感音難聴は，非常にまれな疾患であり，われわれが 検索した限り報告例は認められなかった。聴神経腫瘍の 発見率の上昇と同様に，MRI の普及により小脳橋角部の 病変の検出率の上昇に伴い, 今後上昇するものと考えら れる。また動脈瘤症例は少なからず存在しており，鑑別 診断の一つとして加えられるものと考えられる。

低音域の感音難聴を生ずる疾患としては急性低音障害 型感音難聴が知られており，再発を繰り返すことも少な からず認められる。本症例においても低音域の閾值上昇 を繰り返しており，急性低音障害型感音難聴と考え，ビ タミン剤, 循環改善剤投与と L-V 療法での治療を, さら に浸透圧利尿剤投与を追加して治療を行っていたが，中 音域の閾值上昇をも生じたため中枢性病変を疑い $\mathrm{ABR}$ を施行した. 純音聴力検査では $4 \mathrm{kHz}$ は正常であったが, $\mathrm{ABR}$ ではI波潜時の延長, II 波以降が消失しており, 純音 聴力検查と $\mathrm{ABR}$ 結果に解離を生じていた。純音聴力検 查と比べ ABR は中枢性病変の検出に優れており, 本疾 患の検出の糸口となった。後迷路性難聴が疑われた症例 においては積極的に行らべきと考えられた。

小脳橋角部腫瘍での聴力は正常から壟まで多彩である が，難聴の程度は腫瘍の大きさや脳幹への癒着の有無と は関係なく ${ }^{13)}$, 螖牛神経への圧迫の程度によるとの報告 がある14)。本症例でも難聴は進行しており，大きな未破 裂動脈瘤が徐々に増大し, 蝸牛神経への圧迫が強まって
いったものと考えられる。理論的には，動脈瘤内にコイ ルを充填することにより，心拍動に伴って動脈瘤壁にか かる脈圧が消失し, 神経に対する質量効果が軽減される と考えられている.しかし，本症例は約 $20 \mathrm{~mm}$ もの大 な動脈瘤であったため，わずかに動脈瘤のサイズの縮小 が得られたとしても, 神経に対する質量効果は残存した ものと考えられる.また，コイル挿入後に聾となった原 因としては，挿入操作によるものと，コイル挿入によっ て神経への圧迫がより強くなったことが考えられる。

動脈瘤発症様式としては，破裂によるくも膜下出血が 最も多く, 突発的な激しい頭痛, 嘔気, 嘔吐などの症状 を示す。破裂以外の発症様式は, 警告兆候として各種圧 排症状や微小出血, 微小梗塞による㾏攣や頭痛などが挙 げられている。本症例の耳鳴, 低〜中音域の閾值上昇も, 螖牛神経への圧迫症状による警告兆候として出現してい たむのと考えられる。未破裂動脈瘤が隣接する脳神経, 脳実質に対して，質量効果を呈するようになるには，動 脈瘤のサイズが約 $10 \mathrm{~mm}$ 程度以上に増大した場合であ る。このような症候性の未破裂動脈瘤を未治療のまま経 過をみた場合, 瘤内に血检化を生じて自然治癒するまれ な症例を除いて，ほとんどの症例において神経症状は 徐々に悪化あるいは動脈瘤の破裂をきたし，予後は不良 である15)。

脳動脈瘤の治療としては, 動脈瘤の基部の処理が確実 に行え，根治性が高いため，開頭クリッピングがスタン ダードである。近年，新しい治療法として，血管内手術 
によるコイルを用いた瘤内塞栓術が行われており, 動脈 瘤の直径が $20 \mathrm{~mm}$ 以下の場合, 初回の血管内手術により 良好な塞栓状態が達成されれば，永続的な治療効果が得 られると報告されている16)17)，GDC コイルでは，長期経 過中にコイルが圧縮されることがあり, 開頭クリッピン グと比べて長期安定性にやや劣るものの, 本症例では動 脈瘤が大きいため, 直達手術では患者の肉体的侵襲も多 いことから, 瘤内塞栓療法を選択した。

\section{まとめ}

急性感音難聴で発症した椎骨動脈瘤の1例を経験した. MRIの普及により小腷橋角部の病変の検出率が上昇す るため，今後鑑別診断の一つに加えられるであろう.

内耳性難聴と考えられた症例でも, 経過中に後迷路性 難聴が疑われた場合はただちに ABR, MRI を施行すべき である。

本症例での難聴は，未破裂動脈瘤が増大し蝸牛神経に 対する圧迫により生じたものと考えられた。

本論文の要旨は第 143 回日本耳鼻咽喉科学会東京都地方部会 にて口演した。

\section{参考文献}

1) Wilkins RH : Posterior circulation aneurysms. Neurosurgery Vol 2 (ed by Wilkins RH and Rengachary SS). pp $2341 \sim 2356$, Mc Graw-Hill, New York, 1996.

2) Andoh T, Shirakami S, Nakashima T, et al. : Clinical analysis of a series of vertebral aneurysm cases. Neurosurgery 31:987 993, 1992

3) Inagawa $T$ : What are the actual incidence and mortality rates of subarachnoid hemorrhage? Surg Neurol 47:47 53, 1997.

4) Kojima M, Nagasawa S, Lee $Y E$, et al. : Asymptomatic familial cerebral aneurysms. Neurosurgery $43: 776 \sim 781,1998$.

5) Wiebers DO, Whisnant JP, Sundt TM Jr, et al. : The significance of unruptured intrcranial saccular aneurysms. J Neurosurg $66: 23 \sim 29,1987$.
6) Nehls DG, Flom RA, Carter LP, et al. : Multiple intracranial aneurysms; determining the site of rupture. J Neurosurg 63 : $342 \sim 348,1985$.

7) Shaia FT and Sheely JL : Sudden sensori-neural hearing impairment; a report of 1, 220 cases. Laryngoscope 86:389 398, 1976.

8) Edwards $\mathrm{CH}$ and Paterson $\mathrm{JH}: \mathrm{A}$ review of the symptoms and signs of acoustic neurofibromata. Brain $74: 144 \sim 190,1951$.

9) Hallberg $\mathrm{OE}$ : Sudden deafness of obscure orgin. Laryngoscope $66: 2237 \sim 2267,1956$.

10) Higgs WA : Sudden deafness as the presenting symptom of acoustic neurinoma. Arch Otolaryngol $98: 73 \sim 76,1973$.

11) Pensak ML, Glasscock ME 3rd, Josey AF, et al. : Sudden hearing loss and cerebellopontine angle tumors. Laryngoscope 95 : $1188 \sim 1193,1985$.

12) Berg HM, Cohen NL, Hammerschlag PE, et al. : Acoustic neuroma presenting as sudden hearing loss with recovery. Otolaryngol Head Neck Surg $94: 15 \sim 22,1986$.

13) Selesnick ML and Jackler RK : Atypical hearing loss in acoustic neuroma patients. Laryngoscope $103: 437 \sim 441,1993$.

14) Neely JG : Gross and micro scopic anatomy of the eight cranial nerve in relationship to the solitary schwannoma. Laryngoscope $91: 1512 \sim 1531,1981$.

15) Hashimoto $\mathrm{N}$ and Handa $\mathrm{H}$ : The fate of untreated symptomatic cerebral aneurysms; analysis of 26 patients with clinical course of more than five years. Surg Neurol 18:21 26, 1982.

16) Guglielmi G, Vinuela F, Sepetka I, et al. : Elctrothrombosis of saccular aneurysms via endovascular approach; part 1: Electrochemical basis, technique and experimental results. J Neurosurg $75: 1 \sim 7,1991$.

17) Guglielmi G, Vinuela F, Dion J, et al. : Elctrothrombosis of saccular aneurysms via endovascular approach; part 2: Preliminary clinical experience. J Neurosurg $75: 8 \sim 14,1991$.

原稿受付: 平成 13 年 9 月 3 日

原稿採択：平成13年10月10日

別刷請求先 : 吉川玩磨

T190-8531 立川市錦町 4-2-22

国家公務員共済組合連合会 立川病院耳鼻咽喉科 